MANUEL ALCÁNTARA

MERCEDES GARCÍA MONTERO

FRANCISCO SÁNCHEZ LÓPEZ

(Coords.)
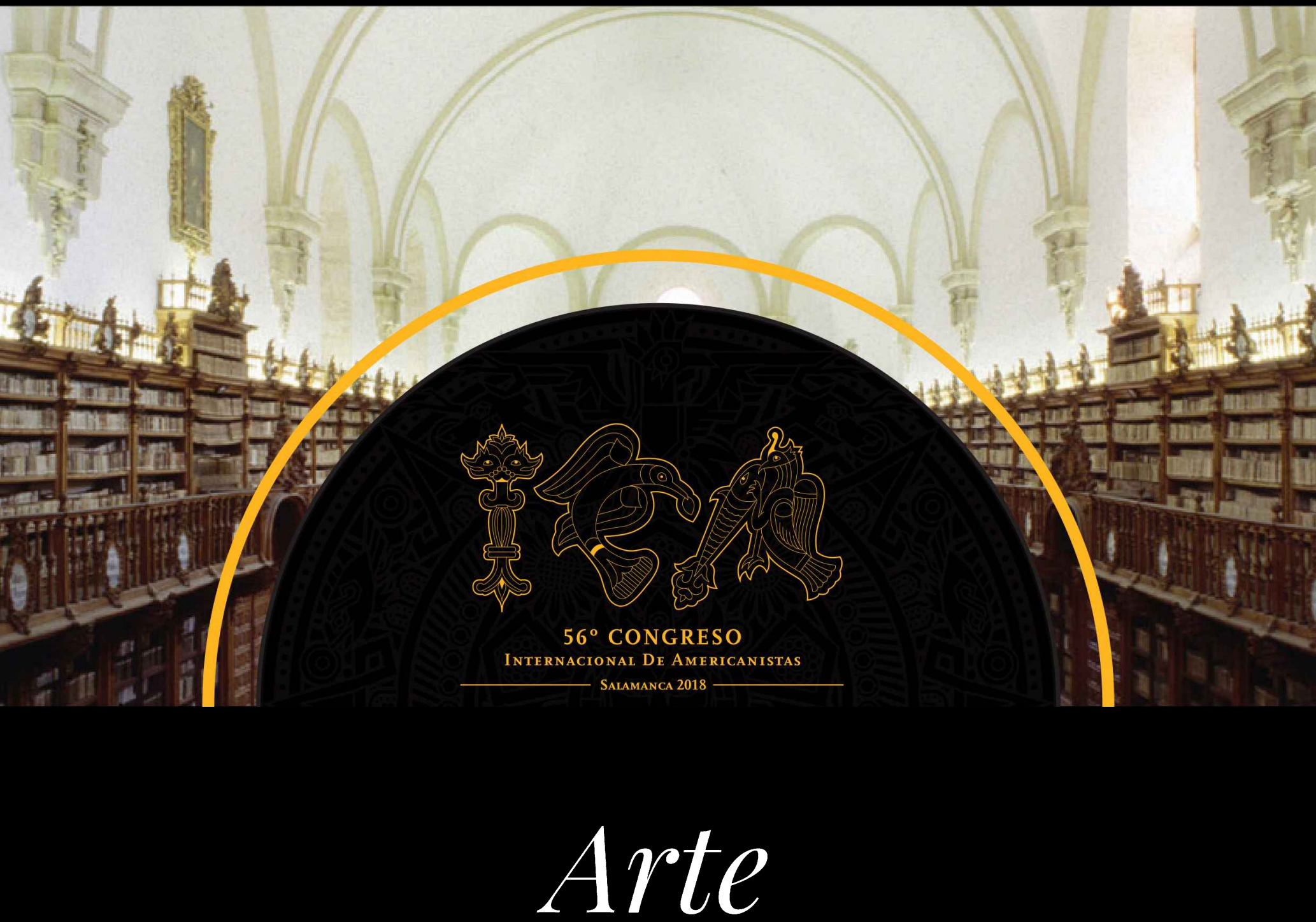

DOI: http://dx.doi.org//10.14201/o\Q(0251_3

Instituto de Iberoamérica

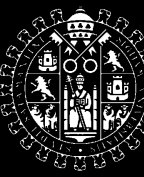

VNiVERSiDAD DSALAMANCA 


\title{
AQUILAFUENTE, 251
}

\author{
(9)(1)(9) \\ Ediciones Universidad de Salamanca y \\ los autores \\ Motivo de cubierta: Idea original de Francisco Sánchez y \\ desarrollado por Clint is Good \\ https://clintisgood.com/ \\ $1^{\text {a }}$ edición: julio, 2018 \\ 978-84-9012-913-5 (pdf obra completa) \\ 978-84-9012-914-2 (pdf, vol. 1) \\ 978-84-9012-915-9 (pdf, vol. 2) \\ 978-84-9012-916-6 (pdf, vol. 3) \\ 978-84-9012-917-3 (pdf, vol. 4) \\ 978-84-9012-918-0 (pdf, vol. 5) \\ 978-84-9012-919-7 (pdf, vol. 6) \\ 978-84-9012-920-3 (pdf, vol. 7) \\ 978-84-9012-921-0 (pdf, vol. 8) \\ 978-84-9012-922-7 (pdf, vol. 9) \\ 978-84-9012-923-4 (pdf, vol. 10) \\ 978-84-9012-924-1 (pdf, vol. 11) \\ 978-84-9012-925-8 (pdf, vol. 12) \\ 978-84-9012-926-5 (pdf, vol. 13) \\ 978-84-9012-927-2 (pdf, vol. 14) \\ 978-84-9012-928-9 (pdf, vol. 15) \\ 978-84-9012-929-6 (pdf, vol. 16) \\ 978-84-9012-930-2 (pdf, vol. 17) \\ 978-84-9012-931-9 (pdf, vol. 18) \\ 978-84-9012-932-6 (pdf, vol. 19) \\ Ediciones Universidad de Salamanca \\ Plaza San Benito, 2 \\ E-37002 Salamanca (España) \\ http://www.eusal.es \\ eus@usal.es \\ Maquetación: \\ Cícero, S.L. \\ Tel.: 923123226 \\ Salamanca (España) \\ Realizado en España-Made in Spain
}

CC Usted es libre de: Compartir — copiar y redistribuir el material en cualquier medio o formato Ediciones Universidad de Salamanca no revocará mientras cumpla con los términos:

(1) Reconocimiento - Debe reconocer adecuadamente la autoría, proporcionar un enlace a la licencia e indicar si se han realizado cambios. Puede hacerlo de cualquier manera razonable, pero no de una manera que sugiera que tiene el apoyo del licenciador o lo recibe por el uso que hace.

GoComercial — No puede utilizar el material para una finalidad comercial.

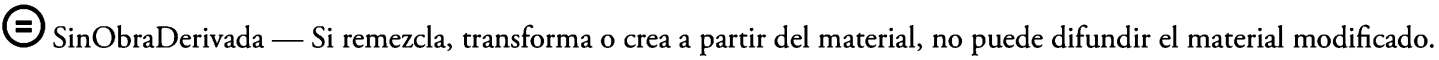

Ediciones Universidad de Salamanca es miembro de la UNE

Unión de Editoriales Universitarias Españolas

www.une.es

Catalogación de editor en ONIX accesible en https://www.dilve.es/ 
$\infty$ Comité permanente $\propto$

Jan-Åke ALVARSSON, Suecia - Presidente ${ }^{\left.\left.\right|^{*}\right]}$

Elizabeth DÍAZ BRENIS, México - Vicepresidente ${ }^{{ }^{*}}$

Walter RAUDALES, El Salvador - Secretario ${ }^{[*]}$

Antonio ACOSTA RODRÍGUEZ, Espańa

Milka CASTRO LUCIC, Chile ${ }^{[*]}$

Horacio CERUTTI GULDBERG, México ${ }^{[* 1}$

Kees DEN BOER, Países Bajos ${ }^{\left[{ }^{*}\right]}$

John R. FISHER, Reino Unido ${ }^{[*]}$

Enrique FLORESCANO MAYET, México

Jorge R. GONZÁLEZ MARMOLEJO, México o ${ }^{[*]}$

Adolfo L. GONZÁLEZ RODRÍGUEZ, España

Martina KALLER, Austria ["]

Jacques LAFAYE, Francia

María Luisa LAVIANA CUETOS, España ${ }^{[*}$

Miguel LEÓN PORTILLA, México

Catalina MACHUCA, El Salvador ${ }^{\left[{ }^{*}\right]}$

Elio MASFERRER KAN, México ${ }^{[*]}$

David MAYER, Austria ${ }^{[*]}$

Berthold MOLDEN, Austria ${ }^{[*]}$

Segundo E. MORENO YÁNEZ, Ecuador ["]

Nohra REY DE MARULANDA, Colombia

Rafael RIVAS POSADA, Colombia

Ramón RIVAS, El Salvador ${ }^{[*]}$

Luis A. RIVEROS CORNEJO, Chile

Mariusz ZIÓLKOWSKI, Polonia ${ }^{* *}$

Con asterisco ${ }^{1 "}$ los miembros del CP-ICA que han asistido a, por lo menos, uno de los tres últimos Congresos:

53 ICA-2009, 54 ICA-2012, 55 ICA-2015.

$\infty$ Comité Científico $\infty$

Antropología

Carmen Martínez-Novo, University of Kentucky

Pablo Palenzuela, Universidad de Sevilla

Arte y patrimonio cultural

Antonio Notario, Universidad de Salamanca

Arqueología

Chris Pool, University of Kentucky

Andrés Ciudad, Universidad Complutense de Madrid

Ciencias y medio ambiente

Barbara Hogenboom, Centre for Latin American Research and Documentation - CEDLA / Universiteit van Amsterdam

Alfredo Stein, University of Manchester

Comunicación y nuevas tecnologías

Ángel Badillo, Universidad de Salamanca

Delia Crovi, UNAM

Cosmovisiones y sistemas religiosos

Elizabeth Díaz Brennis, Escuela Nacional de Antropología e Historia

Mercedes Saizar, CONICET

Educación

José Ma Hernández, Universidad de Salamanca

Pablo Gentili, CLACSO

Estudios culturales

Catherine Boyle, King's College London

Martina Kellar, Universität Wien

Estudios de género

Gioconda Herrera, FLACSO-Ecuador

Arantxa Elizondo, Euskal Herriko Unibertsitatea / Universidad del País Vasco

Estudios económicos

Diego Sánchez, University of Oxford

Andrés Rivarola, Stockholms Universitet 
Estudios políticos

Scott Morgensten, University of Pittsburg

Gisella Sin, University of Illinois

Estudios sociales

Alberto Martín, Instituto Mora

Helene Renee Roux, Institut de Recherche pour le Développement

Filosofía y pensamiento

José Luis Molinuevo, Universidad de Salamanca

Horacio Cerutti Guldberg, Universidad Nacional Autónoma de México

Historia

María Luisa Laviana, CSIC

Ascensión Martínez Riaza, Universidad Complutense

Guillermo Mira Delli-Zotti, Universidad de Salamanca

Lingüística y literatura

Francisca Noguerol, Universidad de Salamanca

Carlos Franz, Academia de Chile

Migraciones

Alberto de Rey, Universidad de Salamanca

Christian Zlolniski, University of Texas at Arlington

Movimientos sociales

Salvador Martí, Universitat de Girona

David Garibay, Université de Lyon 2

Relaciones Internacionales

Sergio Caballero, Universidad de Deusto

Detlef Nolte, GIGA - German Institute of Global and Area Studies

Simposios innovadores

Rodrigo Rodrigues, Universidad de Salamanca

Emerson Urizzi Cervi, Universidade Federal do Paraná

$\bowtie$ Comité organizador local

Presidente

Manuel Alcántara Sáez

Secretario General

Francisco Sánchez López

Vocales

Román Álvarez Rodríguez

Ignacio Berdugo Gómez de la Torre

Miguel Carrera Troyano

Ángel Baldomero Espina Barrio

Mercedes García Montero

José María Hernández Díaz

Guillermo Mira Delli-Zotti,

Francisca Noguerol Jiménez

Emilio Prieto de los Mozos

Antonio Notario

Julio Sánchez Gómez

José Manuel Santos 


\section{PRESENTACIÓN}

\section{Bienvenidos}

El Comité Organizador del $56^{\circ}$ Congreso Internacional de Americanistas (ICA) invita a la comunidad académica a participar en el encuentro que se celebrará en la Universidad de Salamanca el 15 al 20 de julio de 2018. Bajo el lema "Universalidad y particularismo en las Américas», esta edición del ICA llama a la reflexión sobre la dialéctica entre la universalidad y los particularismos en la producción de conocimiento, un diálogo en el que la necesidad de conocer los particularismos de los fenómenos sociales, políticos, artísticos y culturales obliga a formular nuevas hipótesis que enriquecen y replantean las grandes teorías generales de las ciencias y las humanidades.

El carácter interdisciplinario e inclusivo que ha caracterizado al ICA desde su inicio en 1875, como un congreso de estudios de área en sentido completo, hace aún más significativa esa dinámica de producción de conocimiento. Con un planteamiento interdisciplinario e inclusivo, ICA reúne a investigadores que estudian el continente americano, desde Alaska hasta Tierra de Fuego, incluyendo el territorio del Caribe, a partir del análisis de su política, economía, cultural, lenguas, historia y prehistoria. Así, el Comité Organizador les invita a presentar sus propuestas y participar en el análisis y la reflexión sobre las especificidades de las Américas y el Caribe con el objetivo de enriquecer las grandes teorías generales.

\section{Bem-vindo}

O Comitê Organizador do $56^{\circ}$ Congresso Internacional de Americanistas (ICA) convida a comunidade acadêmica a participar do encontro que se celebrará na Universidade de Salamanca de 15 a 20 de julho de 2018. Sob o lema "Universalidade e particularismo nas Américas", esta edição do ICA chama à reflexão sobre a dialética entre a universalidade e os particularismos na produção do conhecimento, um diálogo no qual a necessidade de conhecer os particularismos dos fenômenos sociais, políticos, artísticos e culturais obriga a formular novas hipóteses que enriquecem e reformulam as grandes teorias gerais das ciências e humanidades.

O caráter interdisciplinar e inclusivo que caracteriza o ICA desde o seu início em 1975, como um congresso de estudo de área no seu sentido completo, torna ainda mais significativa esta dinâmica de produçáo do conhecimento. Com um caráter interdisciplinar e inclusivo, o ICA reúne pesquisadores que estudam o continente americano, desde o Alaska até a Terra do Fogo, incluindo o território do Caribe, a partir da análise de sua política, economia, cultura, línguas, história e pré-história. O Comitê Organizador convida-lhes a apresentar suas propostas e participar na análise e na reflexão sobre as especificidades das Américas e do Caribe com o objetivo de enriquecer as grandes teorias gerais.

\section{Welcome}

The Organizing Committee of the 56th International Congress of Americanists (ICA) invites the scholarly community to participate in the congress that will take place in Salamanca from the 15th to the 20th of July of 2018. Under the motto "Universality and particularism in the Americas," this edition of the ICA invites us to reflect on the relationship between universality and particularism in the production of knowledge, a dialogue in which the need to know the idiosyncrasies of social, political, artistic, and cultural phenomena, leads us to create new hypotheses in order to enrich and rethink grand social theories in the sciences and the humanities.

The multidisciplinary and inclusive character of ICA since its beginning in 1875 as an area congress underscores the importance of this dynamic in the production of knowledge. Based on an interdisciplinary and inclusive approach, ICA gathers together researchers who study the politics, the economics, the cultures, the languages, the history, and the prehistory of the Americas, from Alaska to the Caribbean and Tierra del Fuego. The congress welcomes contributions on the specificities of Latin America and the Caribbean. The goal is to enrich social general theories. 


\title{
O TERRITÓRIO COMO SISTEMA. GOVERNO DO ESPAÇO E ARQUITECTURA DA COMPANHIA DE JESUS NA AMÉRICA PORTUGUESA (SÉCULOS XVI-XVIII). O CASO DO ESPÍRITO SANTO
}

\author{
Gomes Duarte, Cláudia \\ Garrido de Oliveira, Carla \\ Pôrto Ribeiro, Nelson
}




\section{O TERRITÓRIO COMO SISTEMA: GOVERNO DO ESPAÇO E ARQUITECTURA DA COMPANHIA DE JESUS NA AMÉRICA PORTUGUESA (SÉCULOS XVI-XVIII). O CASO DO ESPÍRITO SANTO}

$\mathrm{Na}$ primeira parte -antecedentes indígenas e reorganização jesuíta- percorrem-se quatro momentos: [a] breve nota breve acerca da chegada dos jesuítas à capitania, primeiro tipo de assentamento estabelecido e missão a que dão início; [b] aproximação possível à organização e formas de habitar das povoações indígenas, do território à casa; [c] constituição de povoações jesuítas; e em síntese [d] uma exposição sistematizada da organização, evolução e hierarquia do sistema territorial jesuíta.

A segunda parte -o caso de Guarapari- percorre três momentos: [a] movimentações do período indígena; [b] primeiras ocupações e intervenção jesuíta, relevando a orografia de Guarapari na eleição de um sítio para o assentamento e fixação dos missionários, e contributo estratégico da arquitectura na formação do sistema territorial; [c] aproximação à evolução do lugar desde o período jesuíta até à actualidade, procurando perspectivar o seu legado patrimonial, material e imaterial.

\section{ANTECEDENTES INDÍGENAS E REORGANIZAÇÃO JESUÍTA DE UM SISTEMA TERRITORIAL}

\section{I.1 Chegada, primeiros assentamentos e missão}

Chegados ao Brasil, no propósito de firmar contacto com os portugueses e seus escravos, mas sobretudo com as populações indígenas, os jesuítas acompanham igualmente a ocupação do litoral, estabelecendo-se entre o Rio Grande do Norte e São Vicente. A Província dividia-se então em oito capitanias, com sede do Governo-Geral na Bahia, local onde os jesuítas primeiro se estabelecem, seguindo depois para as do Sul e finalmente para as do Norte. [figura f1]

"El rei nosso senhor escreveu ao governador que lhe escrevesse se já havia padres em todas [as capitanias] as quais, sem faltar nenhuma, temos visitadas, e em todas estão padres". (Nóbrega 1551: 67) No sentido desta recomendação, o Padre José de Anchieta informa acerca do Espírito Santo: "[h]á ao longo da costa, oito léguas para o Sul e outras oito para o Norte, quatro ou cinco aldeias de Indios que os nossos visitam por mar e às vezes por terra onde há conversão”. (Anchieta 1580: 227)

"[P]ara que ficasse fundamento da Companhia" e os jesuítas fossem "ganhando terra adiante" (Nóbrega 1552: fl97), os colégios foram os seus primeiros assentamentos. Enquanto na Europa eram implantados nas principais cidades, no Brasil, à semelhança e de acordo com a vontade de D. João III, foram-no na principal vila portuguesa de cada capitania. A partir desse colégio -mesmo quando ainda uma edificação elementar- saíam os missionários em visita às povoações indígenas situadas na proximidade, dando assim início ao processo de evangelização.

O modelo de habitar indígena apresentava contudo grande dificuldade para o processo de evangelização: não era fixo, durando apenas o tempo dos materiais das construções, findo o qual a povoação se estabelecia noutros locais, dividindo-se a tribo (Grã 1557: 560). Este carácter de assentamento móvel será provavelmente o principal motivo que leva os missionários a estabelecer as suas próprias povoações fixas: uma aldeia-cabeça em torno da qual gravitavam aldeias de índios cristãos. Promoviam assim a fixação duradoura 
das populações indígenas em assentamentos jesuítas, no sentido de as evangelizar, mas também de reorganizar, explorar e gerir os seus territórios de domínio.

\section{I.2 Organização e formas de habitar das povoações indigenas}

Do território aos assentamentos [f2]

O nomadismo era uma das características identitárias dos indígenas, ainda que em diferentes graus entre tribos, "de acordo com a pauta da natureza local, da qual dependia para obtenção de alimentos". (Cunha 2015: 254) No Brasil do século XVI as diversas tribos apresentavam assim um modo muito próprio de habitar e organizar o espaço. Fixavam-se no território de modo temporário, mudando a povoação de sítio a cada três ou quatro anos -o tempo de duração dos materiais das construções e o esgotar de recursos naturais. Organizados segundo uma economia de subsistência, não lhes interessaria o estabelecimento fixo. É provável que a incapacidade de realizarem determinadas tarefas associadas à vida sedentária os tenha conduzido a essa constante mobilidade. (Maitam 2017: 456)

Seguindo este princípio de mobilidade territorial, as tabas (aldeias) das tribos que habitavam o litoral apresentavam semelhanças entre si, observando-se contudo diferenças relativamente às tabas das tribos que habitavam o sertão. Referimos concretamente as tribos que viviam no litoral em povoações, como os Tupiniquim e os Tupinambá, maioritárias, e não as tribos minoritárias como os Aimorés, que "não viviam nem em tabas, nem em ocas". (Sousa [1587]: 47-48) A diferença substancial residiria quer na forma dos abrigos quer no facto de as tabas do litoral apresentarem ywara (cerca), enquanto as do sertão as dispensariam. Cada tribo apresentava ainda diferenças quanto ao número e disposição geométrica das ocas (casas), variando a presença e clareza de uma organização em torno da ocára (terreiro); mesmo no caso de tribos inimigas como as Tupiniquim e Tupinambá, podiam assemelhar-se. As tribos indígenas seguiriam assim lógicas organizacionais de estrutura e forma comunitária distribuídas no território, desenho e significação espacial.

No litoral como no sertão todas as tribos seguiriam os mesmos critérios basilares na localização dos assentamentos: “junto aos cursos de água” (Sousa [1587]: 285), fossem rios ou o mar, tanto para deslocações como enquanto fonte de água potável, e em sítios altos ou morros (Staden [1557]: 64-67), embora por vezes um desacerto na escolha ditasse uma mudança antecipada. A ligação entre várias tabas, possivelmente núcleos de uma mesma povoação, compunha um sistema assente quer em caminhos terrestres quer em ligações fluviais ou marítimas. Estes conjuntos ou agregação de tabas, formando uma ou várias povoações, pontuavam um vasto território de domínio pertencente a uma determinada tribo, em faixas quer ao longo da costa quer no sentido do sertão, podendo mesmo compreender a extensão litorânea de toda uma capitania ou parte dela. (Sousa [1587]: 59-67)

\section{Unidades de habitar [f3]}

Cada uma das várias tabas que em conjunto comporiam uma povoação dos Tupiniquim ou dos Tupinambá, dominantes no litoral, possuía uma ou duas ywaras com aproximadamente "braça e meia de altura". (Staden [1557]: 64) É possível que as tabas já tivessem ywara(s) mesmo antes da chegada dos europeus: como o relato de cativeiro e gravuras de Hans Staden parecem demonstrar, mesmo na sua fixação temporária tinham necessidades defensivas, tanto face a tribos inimigas como a animais ferozes. Com a ocupação europeia, a presença de ywara adquire premência defensiva, sobretudo no litoral; nesta função, delimitava e determinava, significando o lugar da taba.

Se por vezes apresentavam disposição menos articulada, atendemos com maior interesse às tabas em que as ocas se distribuíam de modo a conformar um espaço central comunitário: a ocára. A dimensão das tabas era variável, dependendo tanto da dimensão como 
do número de ocas, podendo variar entre três, "quatro e as sete", (Staden [1557]: 80-134) determinando assim um terreiro, variando entre um quadrado e um heptágono, numa certa equidade formal em torno de um espaço estável e agregador.

As ocas, de secção constante, possuíam "geralmente três portas, uma em cada extremidade e outra no centro", tão baixas, que era "necessário curvar-se para sair e entrar". (Staden [1557]: 134-137) Cada casal tinha uma área determinada, contudo sem quaisquer divisórias, destinando-se o espaço central de uma das ocas ao chefe da taba.

\section{I.3 Constituição de povoações jesuitas}

\section{I.3.1 Reorganização estratégica das povoações indígenas}

Estabelecidos na vila portuguesa de cada capitania, principiando por visitar as povoações indígenas -primeiro no litoral, depois pelo sertão-, os jesuítas constatam a já referida relocalização periódica, incluindo a subdivisão do grupo habitante. É possível que desta dificuldade tenha surgido a ideia de reorganizar algumas das povoações indígenas, humana e materialmente, transformando-as em povoações jesuítas, numa estratégia que tirava partido de uma organização e de um sistema territorial já existentes, introduzindo contudo outra noção de hierarquia, subordinação e proveito.

O primeiro acto de ocupação consistiria na simples visita e imposição simbólica de uma cruz. Ajustando os parcos meios de que dispunham às condições de cada situação, os jesuítas implementam três variantes no processo de ocupação, estabelecendo-se [i] numa das tabas da povoação indígena, [ii] a seu lado, ou [iii] transferindo povoações, inclusive de diferentes tribos, para um local por eles determinado, fundando assim uma aldeia jesuíta de raiz.

No primeiro caso, elegendo uma das tabas entre as várias que dispersas compunham a povoação indígena, nela concentravam a população dessas outras "quatro, ou mais" tabas, formando uma só aldeia jesuíta (Nóbrega [1559]: 204-205); aqui residiriam, constituindo cabeça de uma povoação que subordinaria ainda outros assentamentos de visita mais afastados. O segundo caso, similar, diferia apenas no facto de a aldeia-cabeça jesuíta ser exnovo. $\mathrm{O}$ terceiro consistia na transferência de povoações indígenas para um local que fosse mais conveniente aos interesses dos missionários -que além de a Cristo, também ao serviço da Coroa. Entre as várias aldeias de visita, estabeleciam a aldeia-cabeça da povoação jesuíta; se numa povoação indígena habitava apenas uma tribo, a Companhia vai promover a coexistência de várias -com proveito evangelizador, quebrando e confrontando elos intra e entre tribos.

Estabelecida a povoação jesuíta e a partir da aldeia-cabeça, os missionários prosseguiam com a missão, visitando tabas e povoações indígenas no propósito de resgatar outras tribos gentias. Assim, uma povoação jesuíta, além das aldeias cristãs que gravitavam em torno, poderia deter outras, geograficamente mais distantes. (Pires [1560]: fl312) Apenas na aldeia-cabeça de uma povoação existiria o conjunto arquitectónico jesuíta; nas demais aldeias de índios-cristãos, e excepcionalmente em algumas delas, haveria uma construção precária, funcionando como ermida e residência onde, devido às longas distâncias, os missionários pernoitavam nas suas visitas regulares. (Vale [1562]: 475-476)

Nesta estratégia, os jesuítas não só transformam as povoações indígenas em povoações cristãs, cumprindo a sua missão, como impõem um modelo de habitar o território: organizado em sistema hierarquizado, entre concentrado e disperso, e sedentarizado; sobretudo, adquirem legitimidade de proveito e governo das suas vastas áreas de domínio territorial. 


\section{I.3.2 Sistemática e hierarquia: localização, ligações e unidades de produção}

$\mathrm{Na}$ implantação das povoações os jesuítas considerariam quatro factores: [i] sendo as comunicações sobretudo marítimas, existência de baía ou enseada servindo de bom porto, mas simultaneamente defendida, precavendo ataques indígenas ou corsários; [ii] existência de uma foz, estabelecendo ligações ao interior do território; [iii] bons ares, que os morros proporcionavam, bem como água potável (rio, ribeiro ou poço); e [iv] terrenos próximos susceptíveis de cultivo. (Rodriguez 1552: fl68; Pereira [1561]: 335; Gouvea 1583: fl6)

Se muitos destes factores eram considerados pelas populações indígenas antes da chegada dos jesuítas, é a noção de hierarquia e proveito económico, para além da subsistência, que diferencia ambos os sistemas -a uma perspectiva indígena, quotidiana e homogénea, os jesuítas impõem fixação e diferenciação, numa outra visão temporal e material.

Nas visitas regulares às aldeias que compunham a povoação, os jesuítas deslocavamse por terra; igualmente entre povoações em percurso junto à costa, se próximas, como ocorria p.e. entre Guarapari e Reritiba; se distantes, optavam pelo mar.

"[A] mantença da casa é o trabalho de Índios". (Nóbrega [1556]: 152-153) Como garante de sustento próprio, e progressivamente contributo para o sistema, cada aldeia que compunha a povoação tinha as suas terras de produção, com roças, de cultivo, e currais, para criação de animais. Algumas teriam pertencido aos domínios dos índios aldeados, assim tomadas pelos jesuítas, enquanto outras eram doadas pelo Governador ou particulares. A produção era determinada pelo Pe. Visitador, sendo as roças "visitadas a cada semana" pelos missionários, também ensinando a doutrina aos índios (n.a. 1589: fl194-194v); os currais eram-no "pelo menos cada mês" (Gouvea 1589: fl148-148v).

A meados do século XVII, como que em processo de concessão parcial aos índios daquilo que inicialmente deles fora, é determinado que, aqueles que aldeados, pudessem "livremente servir e trabalhar com quem bem lhes estivesse, e melhor lhes pagasse seu trabalho"; àqueles que descessem do Sertão, o Governador assinalaria os lugares convenientes para lavrarem e cultivarem. (Leys Regias 1647: fl6) Em 1660, o Pe. António Vieira redige o "Regulamento das Aldeias", com o propósito de incentivar os índios a produzir excedentes, nas roças e currais, que pudessem ser comercializados pelos jesuítas no colégio.

\section{I.3.3 Arquitectura, forma e construção, nas povoações jesuítas}

A aldeia-cabeça da povoação era formal e hierarquicamente organizada a partir da igreja, com a residência anexa, ambas presidindo um amplo espaço aberto, terreiro agregador das habitações dos indígenas.

Porém, o que primeiro construíam era um abrigo rudimentar em taipa-de-mão e palha que funcionava como ermida, residência e escola de doutrinação e ensino elementar. (Nóbrega 1549/1551: fl66/47v) Posteriormente esse abrigo era substituído pela igreja construída em taipa-de-pilão, a que sucederia a igreja definitiva, de pedra e cal. (Grã 1552: fl112v) Enquanto não davam início ao edifício da residência, acrescentavam à igreja "algunos aposentos para estar mejor acomodados", anexos à capela-mor, onde residiam os jesuítas (n.a. 1562: fl12v), passando a funcionar como sacristia aquando da construção da residência.

Similar a um convento ou ao colégio na sede da capitania, mesmo que mais elementar, a residência era composta por três alas, formando com a igreja uma construção em quadra. A cada piso e a cada ala correspondia um uso específico: no sobrado, os cubículos e a escola de ensino elementar; no piso térreo, as oficinas e a cantina. (Martins 1994) Face a esta 
organização de três alas em torno de um pátio-claustro, observa-se também a construção de apenas uma ala, de maior largura.

Nas oficinas os jesuítas instruíam os índios nas pequenas indústrias artesanais formando pedreiros, ferreiros, carpinteiros, oleiros, ... mão-de-obra especializada fundamental para a edificação e manutenção dos assentamentos, que circulava dentro do próprio sistema territorial jesuíta -"destes moços, pus a aprender ofícios quatro ou cinco e isto se há-de fazer com outros". (Grã 1553: fl166) Esta mão-de-obra indígena especializada era também, pela qualidade, requerida pelo Governador para serviços e obras públicas da capitania.

As habitações das populações indígenas distribuíam-se em redor do terreiro, agregador e relacional, como que reminiscente da ocára nas tabas indígenas. Ao contrário do que ocorria com as ocas comunitárias, vão ser individuais, compostas igualmente por apenas um piso, com materiais e sistema construtivo elementares, em "madeira e palha ou em taipade-mão e palha" (Nóbrega 1552: fl97), plausivelmente numa metamorfose das barracas compridas dos gentios, agora autonomizando o espaço de cada casal, abrindo individualmente para o terreiro.

\section{I.3.4 Número de missionários e hierarquização do sistema territorial}

De início cada povoação tinha um padre, superior com cerca de 40 anos, e um irmão, com metade da idade competindo-lhe aprender a língua indígena. Porém, porque alguns aderiam ao modo de vida dos índios gentios, Francisco de Borja determina a permanência de quatro missionários por povoação, dois padres e dois irmãos. Devido aos parcos recursos humanos, inviabilizando a residência permanente de quatro missionários em todos os assentamentos-cabeça, Cláudio Acquaviva determina que as povoações que não os pudessem ter passassem a ser de visitação. (Roma 1598: fl131) Emanada de Roma, a medida é refutada pelos jesuítas no Brasil, insistindo na importância das povoações e na permanência constante de missionários, tanto para sua conservação como para conversão de gentios. Volta assim a entrar em vigor a directiva de permanência de dois missionários, um padre e um irmão -se possível, três ou quatro-, determinando ainda que visitassem "las casas de los Indios una vez en la semana, o mas si fuere necessário”. (Roma 1598: fl146)

Em consequência, algumas aldeias-cabeça de residência passam de permanente a pendular, i.e., de missão a visitação, como foi p.e. o caso de Guarapari, evidência da capacidade de adaptação, ou miscigenação, entre o modelo jesuíta e o contexto.

\section{1- Posição estratégica no território| costa}

Tendo a Companhia de Jesus estabelecido povoações ao longo de todo o litoral, não será difícil imaginar, em território tão vasto e pouco ocupado, uma costa pontuada pelos seus assentamentos e edifícios, uma imagem que, à época, traduzir-se-ia numa paisagem manifestamente jesuíta -uma paisagem onde a arquitectura da Companhia se destacava no território como verdadeira marca de ocupação, proveito e governo.

Assim, os assentamentos jesuítas não foram apenas núcleos de evangelização e educação de populações indígenas, centros de produção e ofícios; estiveram também eles incluídos na defesa costeira, ainda que sob o seu aspecto religioso, e portanto pacífico e inofensivo, constituindo efectivas fortificações, do espiritual e do temporal, desempenhado funções de defesa passiva sob uma expressão religiosa, como parece demonstrar a documentação epistolar da época. 


\section{I.4 Organiz̧ą̧ão, evolução e bierarquia do sistema territorial jesuita [f4-f5]}

Fundado o colégio na vila da capitania, os jesuítas estabelecem povoações a Norte e a Sul com o propósito de evangelizar as populações indígenas, mas também de garantir a ocupação, proveito e governo do território ou, segundo o Pe. Nóbrega, de a terra povoar. Dependendo das directivas romanas, as aldeias-cabeça das povoações jesuítas, todas de residência, oscilavam entre a plena condição de missão ou apenas enquanto de visitação. As de missão caracterizavam-se por terem residência permanente de missionários, enquanto as de visitação, devido à insuficiência de recursos humanos na Província, oscilavam entre a permanência prolongada, ou mesmo a simples pernoita por alguns dias, e certos períodos de ausência. Todas elas, além de centros de catequização e doutrinação funcionavam como escola: de ensino elementar para os índios menores e de ofícios para os índios adultos.

No Espírito Santo foram duas as aldeias de missão, Reis Magos e Reritiba, a Norte e a Sul do colégio em Victoria, aproximada e respectivamente no centro da distância compreendida entre este e os limites da capitania, nos rios Doce e Paraíba. As aldeias de visitação foram também duas, São João e Guarapari, a meia distância entre aquelas de missão e o colégio.

Em torno de todas, bem como do colégio, gravitavam as aldeias de visita, tabas cristianizadas ou aldeias de índios cristãos, cujas populações os jesuítas doutrinavam e catequizavam, visitando-as frequentemente; fixas, estas aldeias subordinavam-se às aldeiascabeça, constituindo as povoações. Em algumas existiria uma construção precária, abrigo funcionando tanto como ermida como casa; a distância entre algumas aldeias era significativa, justificando-se assim a pernoita dos missionários.

Garantia de sustento do Instituto na Província, os jesuítas iniciam a administração de fazendas e engenhos, primeiro doados, depois implementados por iniciativa própria. À semelhança das aldeias-cabeça, estas unidades produtivas vão também desempenhar função organizadora e de significação do território, bem como características 'urbanas' e arquitectónicas similares -igreja, residência e terreiro, delimitado por habitações e construções de apoio à produção. Diferença substancial entre a residência das povoações face àquela das fazendas e engenhos estava no facto de as primeiras, além de habitação, albergarem também espaços de catequização e de ensino elementar.

Entre a aldeia-cabeça das povoações e o colégio circulava o material de construção e a mão-de-obra especializada formada pelos missionários, fundamental na consolidação dos conjuntos arquitectónicos jesuítas bem como na sua manutenção. A produção proveniente sobretudo das fazendas e engenhos era enviada ao colégio, por via terrestre, fluvial ou marítima, a partir do qual era redistribuída, por determinação dos superiores de acordo com as necessidades, pelas aldeias-cabeça das quatro povoações -Reis Magos e Reritiba, São João e Guarapari-, ou mesmo comercializando o excedente.

Estas frequentes deslocações entre estalagens jesuitas por toda a costa foram assim inscrevendo no território uma rede de ligações materiais e imateriais-caminhos da terra como do mar, povoando a terra. As primeiras ligações, surgidas da necessidade de assegurar a evangelização das populações indígenas, acabaram assim reforçadas por um sistema económico-administrativo que visava garantir o auto-sustento jesuíta na Província. Com assentamentos hierarquizados e estrategicamente implantadas ao longo do Espírito Santo, ligados por rotas terrestres e trajectos marítimos e fluviais, os missionários ao serviço da Igreja e da Coroa, com as populações indígenas a seu serviço, garantiam uma significativa área de acção territorial, construindo e contribuindo para uma matriz de povoamento organização, proveito e governo do espaço. 


\section{O CASO DE GUARAPARI}

\section{II.1 1556|1558-1569 Movimentações do periodo indígena}

Fundada uma aldeia em 1556 a 12 léguas da vila da capitania, o Gato, chefe dos Temininós recebe autorização do Governador para se estabelecer com a sua tribo em terras situadas junto a Victoria. (Leite 1938: 238-240) Porém, em 1568, a tribo divide-se, aqui ficando uns com o Gato, outros seguindo para Guarapari chefiados pelo irmão, Cão Grande. O sítio para a fixação da povoação indígena é determinado pelo Governador: a Sul, cerca de "seis léguas próximo ao mar", sendo propósito dos jesuítas visitar a povoação logo que começassem a "assentar e fazer suas casas", no sentido de saber se teriam algum proveito. (Pires 1558: 221)

Este hiato entre 1556-1558, correspondendo à passagem por Victoria, parece esclarecer acerca do ano em que efectivamente os Temiminós se estabelecem em Guarapari, já que existe alguma divergência: para Bazílio Daemon essa transferência principia "em 1556 [...], a 12 léguas de distância da Villa de Victoria" (Daemon 1879: 69); já para Serafim Leite S.J. ocorre "em 1558" (Leite 1938: 242).

Novamente divergente, a bibliografia acerca do ano de fixação dos missionários não chega a ser contraditória: para Daemon ocorre em "1569 por iniciativa do Padre José de Anchieta, que sobre a aldeia indígena fundou a aldeia de Guarapari" (1879: 69); segundo Leite, "em 1585, fundaram os jesuítas uma residência no alto da embocadura do Rio Guarapari, onde edificaram uma igreja de invocação a Santa Ana”. (1938: 242) Primeiro assentamento jesuíta situado a Sul do colégio, é assim possível estabelecer que o foi em 1569 convertendo uma taba indígena, numa outra localização, relocalizando-a enquanto aldeiacabeça em 1585 no sítio actual.

\section{II.2 1585-1679 Período jesuita: implantação e construção do lugar}

\section{II.2.1 Topo-hidrografia e fundação}

A foz do Rio Guarapari abre em grande baía pontuada a Sul por uma penínsulacolina, recortada por quatro pequenas enseadas, uma aberta ao rio e três ao mar; junto da enseada a Nordeste, um poço de água potável. Modelada por dois morros, os missionários estabelecem no mais alto a aldeia-cabeça da povoação, implantando no topo Nordeste o conjunto arquitectónico, igreja e residência, voltado a Sudoeste presidindo o terreiro.

\section{II.2.2 Aldeia-cabeça de residência, entre missão e visitação}

"[E]m 1587 o Padre José de Anchieta recebe na Aldeia o Padre Provincial, Marçal Beliarte, recém-chegado do reino", tendo sido "residência estável dos jesuítas até finais do século XVI" (Leite 1938/1945: 242/144). "[E]m 1597 residiam na aldeia de Guarapari os Padres António Dias e Manuel Dias" (Vasconcelos [1663] 1953: 329), sendo que "em 1600, o Padre António Dias de Reritiba ia visitar Guaraparim por aquela praia de cinco léguas de areia cruel". (Rodrigues 1600: fl170v)

Assim, Guarapari terá sido aldeia-cabeça de missão, se não desde 1585, pelo menos a partir de 1587 até 1597; considerando que o Pe. António Dias, residente em 1597 mas de Reritiba em 1600, é o mesmo, Guarapari terá passado da condição de missão à de visitação. No âmbito das determinações romanas do final de Quinhentos quanto ao número de missionários por assentamento, bem como por força da implementação de um sistema territorial em permanente redesenho, entre 1597 e 1600 Guarapari terá sido preterida a favor de Reritiba enquanto missão a Sul de Victoria. Para o período 1600-1679 não foi encontrada 
documentação que informasse sobre a sua condição, mas é possível tenha retomado a residência permanente, uma vez que data do final do XVI nova autorização romana para dois missionários (Leite 1945: 144).

Enquanto de residência permanente, a povoação teve sob sua jurisdição [f5] as aldeias de Una e Perocão, a Norte; Campo, a Poente; e Meaipe e Maembã, a Sul (Gazeta 1999), a meio daquela praia de cinco léguas de areia cruel a caminho de Reritiba. $\mathrm{Na}$ esfera desta última passam a inserir-se tanto Guarapari enquanto residência de visitação como as suas aldeias de visita.

Em 1679, os jesuítas abandonam a povoação e meses depois o donatário, por carta de foral, eleva a vila a antiga aldeia-cabeça jesuíta.

\section{II.2.3 Transformações do lugar -territoriais, urbanas, arquitectónicas [f6]}

Já referido, é apontado o ano de 1585 como de fundação da residência e igreja, de invocaşão a Santa Ana, hoje contudo a NS da Conceição. "Entre 1677-79, fronteira à igreja dos jesuítas foi edificada a igreja do Donatário da capitania" (Lidwin 1946). Em documentação da segunda metade de Oitocentos, incluindo cartografia de 1863, a igreja jesuíta a Norte é dada como capela em ruinas, abandonné, enquanto a do donatário a Sul é identificada como matrizpequena, ou église.

A primeira foi entretanto reconstruída pelo IPHAN, enquanto esta última, hoje em ruína e identificada in loco como igreja de NS da Conceição, evidencia algumas semelhanças com a dos jesuítas, nomeadamente nas dimensões e na configuração da torre. Observa-se assim entre as duas igrejas uma curiosa migração e inversão, tanto no que respeita ao orago como à condição de ruína.

Transformada de jesuíta em residência do donatário, os registos de construção da ala contígua à igreja, a Nascente, apontam para que a mesma tivesse cerca de $20,24 \mathrm{~m}$ por $14,96 \mathrm{~m}$ : “o Convento tem 92p de comprimento e 68p largura" (Neuwied 1815-17: 139).

Fronteira à igreja existe hoje uma praça sensivelmente quadrada, que poderá corresponder ao todo ou a parte do antigo terreiro [f7]; é possível que os jesuítas, aquando da fundação de uma aldeia-cabeça, tomassem aproximadamente como referente a ocára, espaço central de uma taba indígena. É difícil precisar com rigor a configuração de tal terreiro mas, na cartografia consultada, 1790 e 1863, observa-se que o conjunto arquitectónico jesuíta e a igreja do donatário são mediados pela enorme chapada, pontuada apenas por uma arbre remarquable; assim, é até possível que toda esta extensão correspondesse ao antigo terreiro.

O conjunto arquitectónico jesuíta está hoje inserido em tecido urbano, contudo recente, posterior a meados do século $\mathrm{XX}$, conforme registos do processo de tombamento e intervenção do IPHAN. Perdeu-se a leitura da unidade antiga do conjunto que caracterizaria Guarapari entre os séculos XVI-XX, a nível territorial como paisagístico, e que muito se deveria ao protagonismo sobre o morro do conjunto arquitectónico jesuíta, da igreja do donatário e do enorme espaço que as mediava, conferindo-lhes a força de uma "paisagem notável" (Carloni 1946). Contudo, permanece a força referencial e estruturante da igreja jesuíta e do terreiro fronteiro, no qual desemboca a Rua Matriz, em cuja ilharga se encontra a ruína da capela do donatário e que, permanecendo, conferiram clareza às profundas transformações ocorridas nas últimas décadas. Tais elementos, na harmonia do conjunto e na sua transformação, constituíram e constituem marca legível no território e na paisagem. 


\section{CONSIDERAÇÕES FINAIS}

Uma presença maior do tempo antigo -um olhar sobre a história, o passado e o património material e imaterial- não traduz uma saudade de um tempo que não foi o nosso, nem por nós vivido, antes notando a inquestionável presença e influência das povoações indígenas, primeiro, e a reorganização do povoamento implementada pelos jesuítas, depois, para aquilo que é hoje o território brasileiro.

Determinadas em Roma, as povoações jesuítas foram o resultado da acção dos missionários no Brasil, na adequação à geografia, à paisagem e ao modo de vida das populações indígenas; não emanou do epicentro romano mas dos próprios missionários na colónia, de onde a sua localidade e singularidade.

Roma foi reconhecendo este modo de povoar, reorganizando e reestruturando, engenho jesuíta na conversão espiritual e material como a forma missionária mais adequada à realidade indígena. Evangelização, exploração produtiva e expansão territorial, a missão jesuíta no Brasil concretiza-se na construção de um sistema de assentamentos hierarquizados e conectados tanto por terra como por rio e mar.

Certos aspectos na implantação e organização das povoações indígenas, apropriados nas povoações jesuítas, quase conduzem a considerar a imprescindibilidade das primeiras para a concretização do projecto missionário. As tabas indígenas, nomeadamente as ócaras enquanto praças da comunidade, terão servido como referência para os assentamentos jesuítas. Enveredando pela construção durável e variação de escala, conferindo hierarquia e significado a cada assentamento dentro do sistema territorial, parece evidenciar-se uma matriz comum entre as povoações indígenas e as povoações jesuítas. Apesar de por imposição, os jesuítas operaram assim também a partir da realidade indígena, convertendo tanto no espiritual como no temporal. 


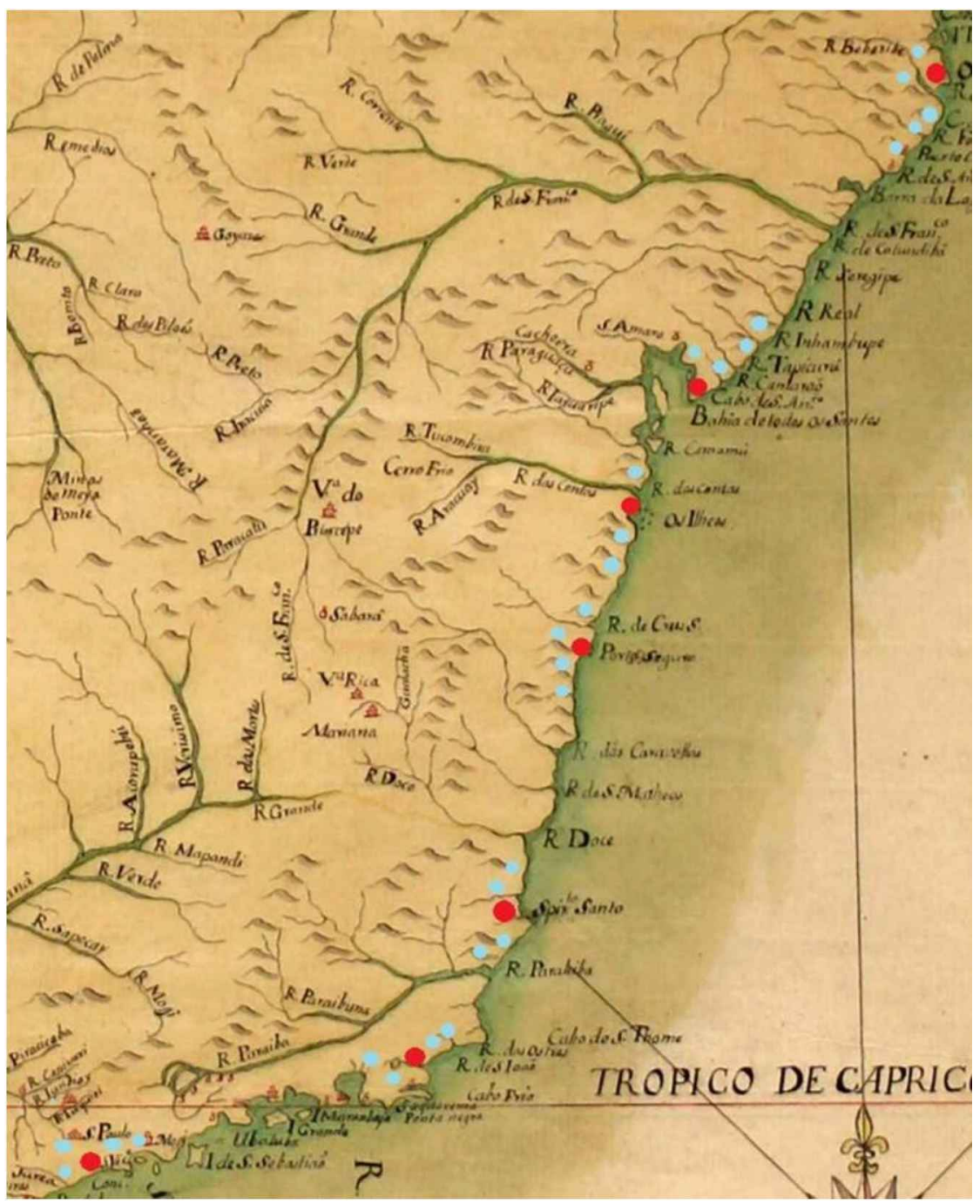

[f1] " $[\mathrm{H}]$ averia estalagens de cristãos por toda a costa, assim para os caminhantes da terra como para os do mar. Este parece tão bem o melhor meio para se a terra povoar". (Nóbrega 1558: fl78) [CGD sobre "Mapa de los confines del Brazil", s.d.]

"Em año de 1549 fui embiado [...] a estas partes com mis cinco compañeros, [...] para aver colégios de nustra Compañia, o recogimiento para hijos de los gentiles, que yo pidiesse tierras al Governador y escogiesse sítios". (Nóbrega 1561: fl116)

"E em quanto nas dittas povoações estiverem, os dittos Religiosos da Companhia os terão [aos índios] a seu cargo assi no que convem ao espiritual da Doutrina Christã, como para que quando forem necessários para meu serviço [Rei] os apresentem ao Governador, ou Capitão geral”. (1609: fl 3) 

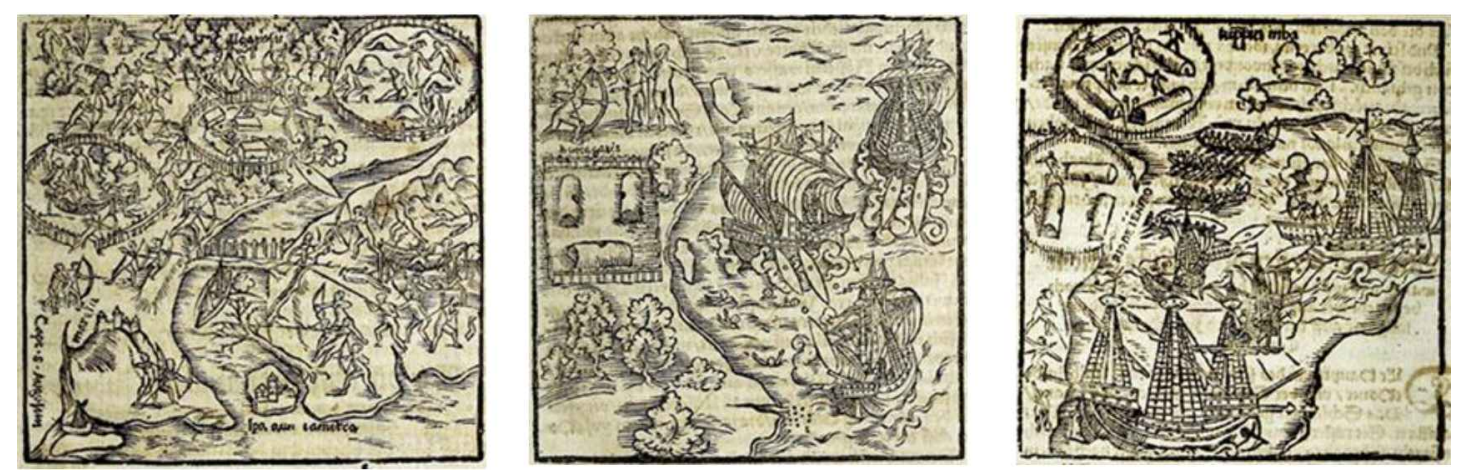

[f2] Organização e formas de habitar das povoações indígenas, do território aos assentamentos [Staden 1557]

"Sua morada he commummente, como de gente isenta de leis, de jurisdícção, de republica, por onde quer que melhor lhes parece; huns pelos montes, outros pelos campos, outros pelas brenhas; [...] ora em huma, ora em outra parte, segundo os tempos do anno, e as occasiôes de suas comedias, caças, e pescas; sem pátria certa." (Vasconcelos [1662]: LXXVI)

"[S]on tán acostumbrados a se mudar cuando sus casas son viejas, que cada três o quatro años que ellas duran se mudan, y lo que es peor no van juntos, y por esta causa se pierde em mui poco tiempo quanto com ellos se trabajan em muchos años". (Grã 1557: 560)
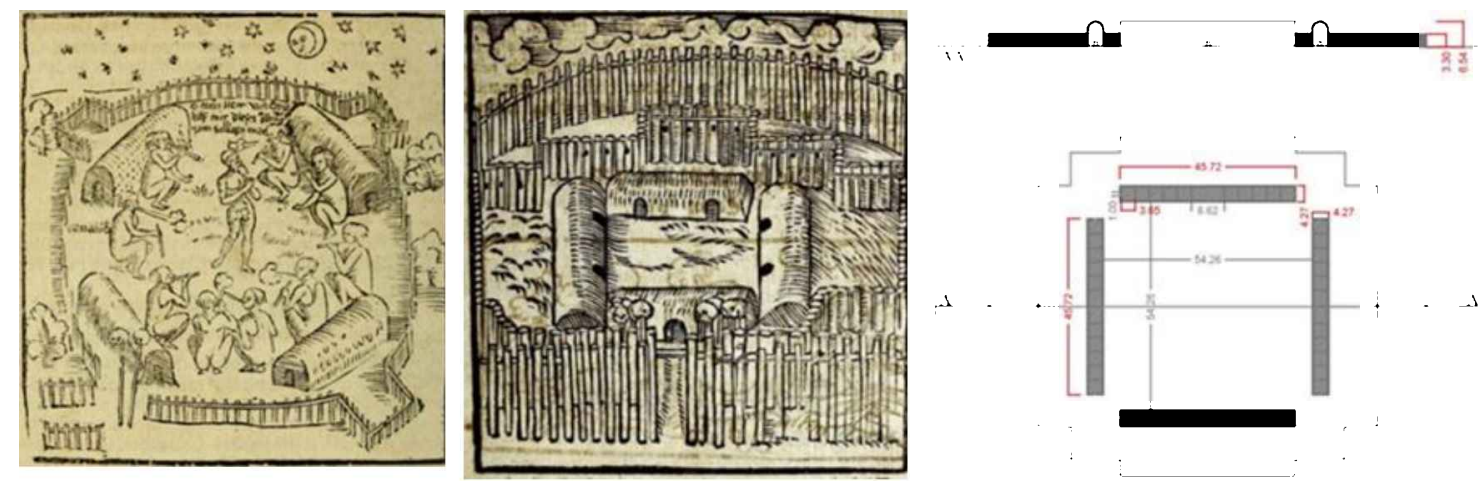

[f3] Unidades de habitar indígena: taba (aldeia), ywara (cerca), oca (casa), ocára (terreiro) [Staden 1557; CGD; Cunha 2015: 241]

“Os abrigos de huns, são humas pequenas choupanas, armadas á mão em quatro páos, cobertas de palha, ou palma, como aquellas que hoje servem, e á manhãa se queimão. Outros que tem mais semelhança de communidade humana, formão cabanas, ou barracas compridas, desde o principio até o cabo, sem repartimento algum: entremeio alojão dentro vinte, até trinta casaes: d'estes cada qual se arrancha de hum esteio até outro com seu c[h]ão, e fogo, que sempre tem comsigo; e aqui vivem juntos todos". (Vasconcelos [1662]: LXXVI) 


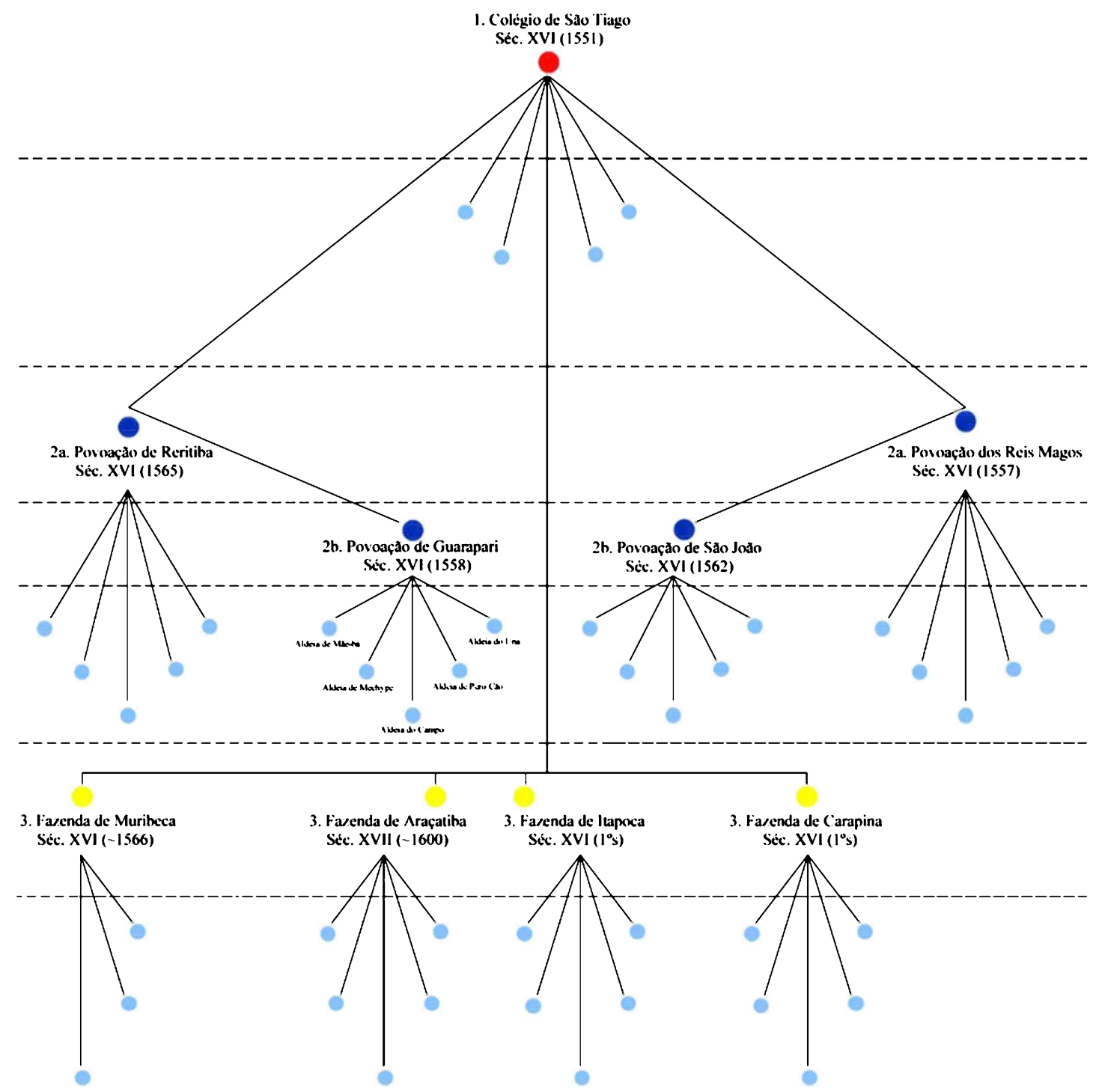

[f4] Sistema territorial jesuíta, capitania do Espírito Santo, XVI-XVII, esquema [CGD] 

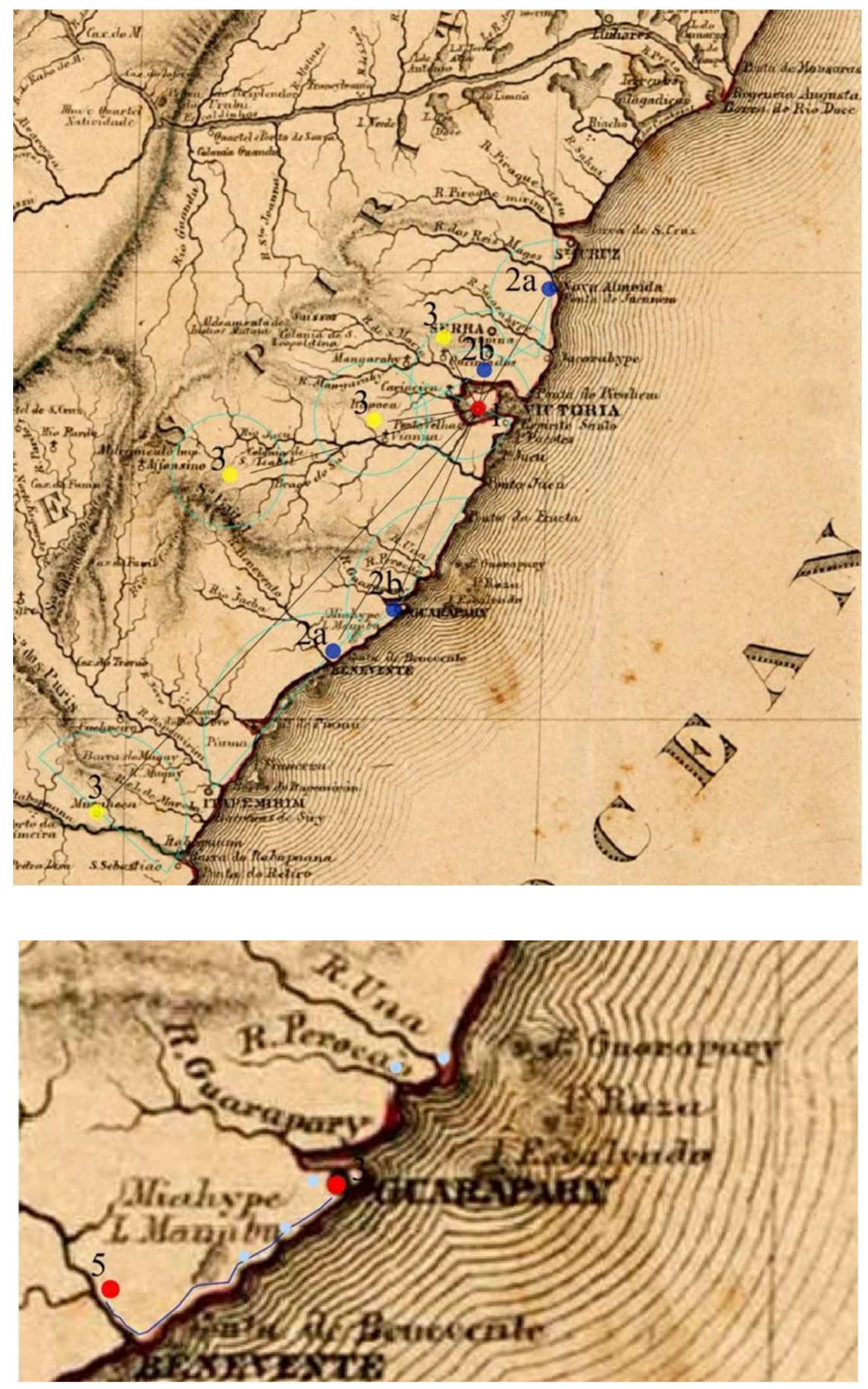
mapeado

[f5] Sistema territorial jesuíta, capitania do Espírito Santo, XVI-XVII, esquema

[CGD sobre Mapa da "Província do Espírito Santo", 1875]

"Guarapari talvez fosse uma das dez aldeias existentes, em 1581, ao longo da costa do Espírito Santo, que era visitada periodicamente pelos jesuítas". (Leite 1938: 242) 

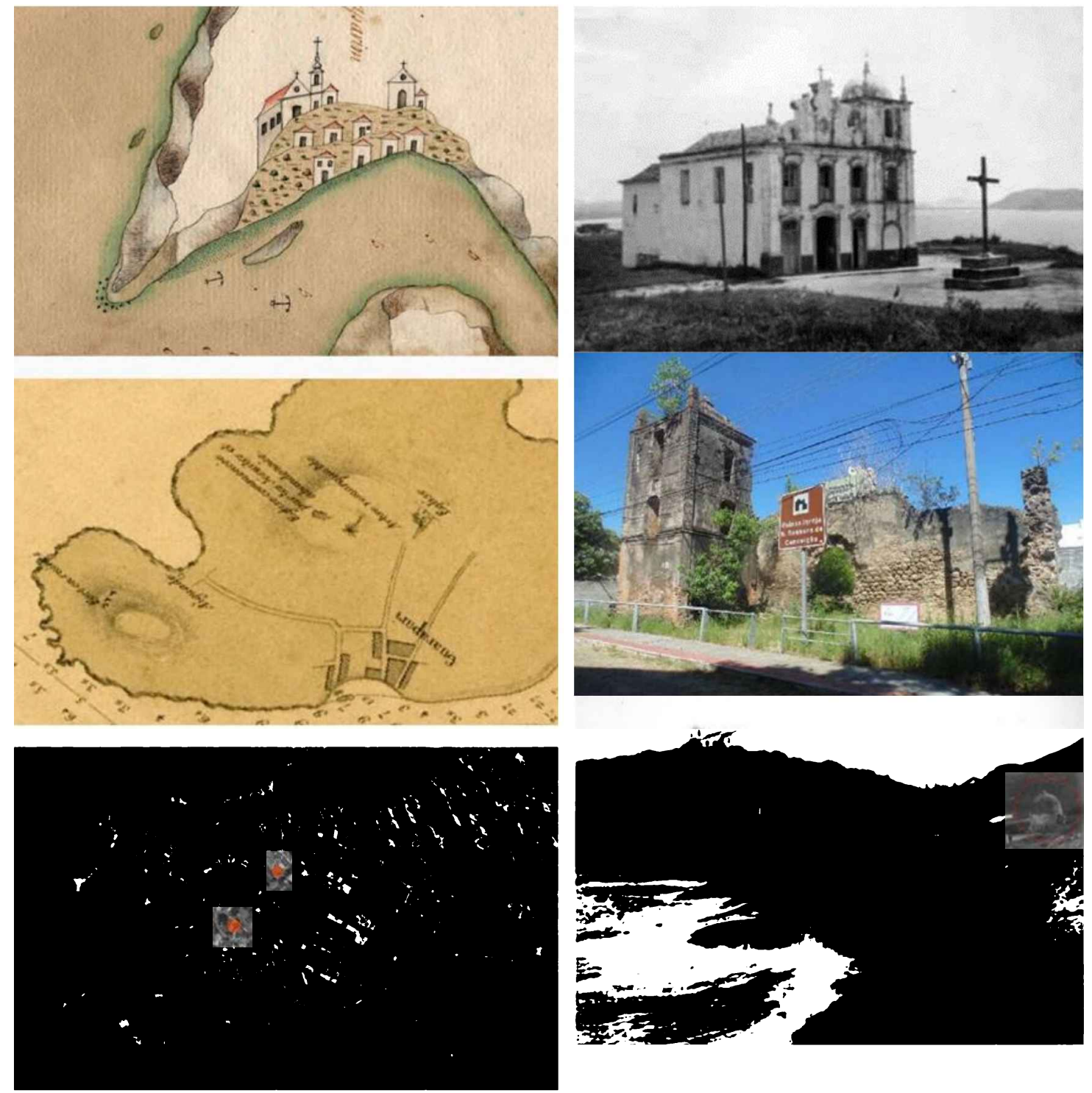

[f6] O conjunto jesuíta (igreja, terreiro e cruzeiro) e as ruínas da capela do donatário no alto da embocadura do Rio Guarapari [excertos de cartografia (aproximadamente orientada a Sul), 1790 AHUL, 1863 AHERJ, BingMaps 2018; ACIPHAN-SRJ (direita-superior-centro), CGDjan18 (direita-inferior)]

"A rua maior estende-se ao longo do cimo duma colina e a vila tem bastantes casas de telha e algumas de sobrado. A matriz pequena está na parte superior da vila numa chapada tendo de frente em ruínas a capela e casa do arcediago Quental que era dono da fazenda onde se levantou a vila. A capela havia de ser bonita e a casa contígua é de sobrado com 6 janelas de frente, mas pouco fundo". (D. Pedro II [1860]: 216)

Observa-se a existência de pequenas habitações, em número reduzido, no sopé do morro e orientadas para o estuário.

"No território, determinados sítios excepcionais na paisagem natural foram sendo eleitos como lugares especiais de edificação. [...] Assim, assinalam-se os sítios no território, transformando-os em lugares de significação extraordinária (lugares de culto e de devoção) e/ou lugares de apetência gregária (como géneses de aglomerados urbanos)". (Pinto da Silva 2009: 343) 


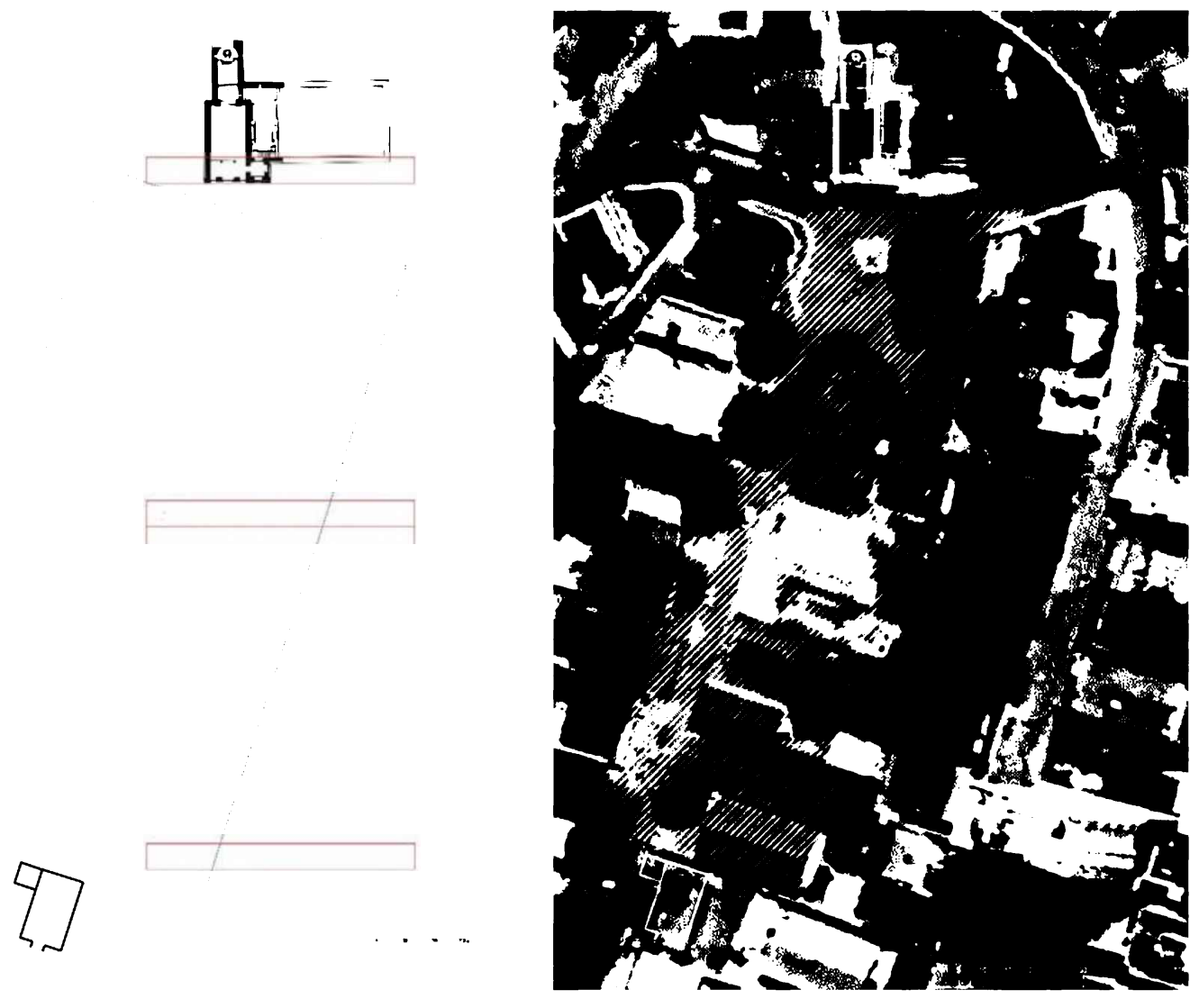

[f7] Guarapari, transformações do lugar -territoriais, urbanas, arquitectónicas

[CGD sobre BingMaps 2018]

IV. REFERÊNCIAS -FONTES DOCUMENTAIS, TEXTUAIS E ICONOGRÁFICAS; OUTRA BIBLIOGRAFIA-

\section{IV.1 FONTES PRIMÁRIAS}

"Carta do Padre Manoel da Nóbrega, enviada de Pernambuco, a 11 de Agosto de 1551, ao Padre Simão Rodrigues em Lisboa". In HUE, Sheila Moura. Primeiras Cartas do Brasil (1551-1555), Jorge ZAHAR Editor, Rio de Janeiro, 2006.

(Nóbrega [1551]: fl000, em fólios)

"Informação do Padre José de Anchieta em 1580 acerca da capitania do Espírito Santo". In ANCHIETA, José de. S. J. Cartas, Informações, Fragmentos Históricos e Sermões (1554-1594), Editora Itatiaia Limitada/Editora da Universidade de São Paulo, Belo Horizonte/São Paulo, 1988.

(Anchieta [1580]: fl000)

"Carta manuscrita do Padre Manoel da Nóbrega ao Padre Simão Rodrigues, em Lisboa, da Baía a x de Julho de 1552". In Archivum Romanum Societatis Iesu, Roma. Fonte: Brasiliae 3-1 (1550-1660).

(ARSI, [1552], 000) 
"Carta do Padre Manoel da Nóbrega, enviada de Pernambuco, a 11 de Agosto de 1551, ao Padre Simão Rodrigues em Lisboa". In HUE, Sheila Moura. Primeiras Cartas do Brasil (15511555), Jorge ZAHAR Editor, Rio de Janeiro, 2006.

(Nóbrega, [1551], 000)

"Informação do Padre José de Anchieta em 1580 acerca da capitania do Espírito Santo". In ANCHIETA, José de. S. J. Cartas, Informações, Fragmentos Históricos e Sermões (1554-1594), Editora Itatiaia Limitada/Editora da Universidade de São Paulo, Belo Horizonte/São Paulo, 1988.

(Anchieta, [1580], 000)

"Carta manuscrita do Padre Manoel da Nóbrega ao Padre Simão Rodrigues, em Lisboa, da Baía a x de Julho de 1552". In Archivum Romanum Societatis Iesu, Roma. Fonte: Brasiliae 3-1 (1550-1660).

(ARSI, [1552], 000)

"Carta do Padre Luís da Grã ao Padre Inácio de Loyola, de Piratininga, em 7 de Abril de 1557, para Roma". LEITE, Serafim S. I. Monumenta Brasiliae I (1538-1553), Monumenta Histórica Societatis Iesu, Roma, 1556.

(Grã, [1557], 000)

SOUSA, Gabriel Soares de. “Tratado Descritivo do Brasil em 1587”, Typografia de João Ignacio da Silva, Rio de Janeiro, 1875.

(Sousa, [1587] 1875, 000)

STADEN, Hans. "Viagem ao Brasil", 1520-1565 (1ºd.), Academia Brasileira, Rio de Janeiro, 1930.

(Staden, [1557] 1930, 000)

"Carta do Padre Manoel da Nóbrega, de 1559 da Bahia, a Tomé de Sousa". In NÓBREGA, Manoel da. S. J. Cartas do Brasil (1549-1560), Editora Itatiaia Limitada/Editora da Universidade de São Paulo, Belo Horizonte/São Paulo, 1988.

(Nóbrega, [1559], 000)

"Carta do Padre António Pires aos Padres e Irmãos de Portugal, da Baía, a 22 de Outubro de 1560". In LEITE, Serafim S. I. Monumenta Brasiliae, III (1558-1563), Monumenta Histórica Societatis Iesu, Roma, 1558.

(Pires, [1560], 000)

"Carta do Padre Leonardo do Vale por comissão do Padre Luis da Grã, da Baía, aos Padres e Irmãos de São Roque, em Lisboa, a 26 de Junho de 1562". In LEITE, Serafim S. I. Monumenta Brasiliae, III (1558-1563), Monumenta Histórica Societatis Iesu, Roma, 1558.

(Vale, [1562], 000)

"Carta manuscrita do Padre Vicente Rodriguez, da Baía a 12 de Setembre de 1552". In Archivum Romanum Societatis Iesu, Roma. Fonte: "Brasiliae 3-1 (1550-1660)".

(ARSI, [1552], 000)

"Carta do Padre Rui Pereira aos Padres e Irmãos de Portugal, de Pernambuco, em 6 de Abril de 1561". In LEITE, Serafim S. I. Monumenta Brasiliae, III (1558-1563), Monumenta Histórica Societatis Iesu, Roma, 1558.

$$
\text { (Pereira, [1561], 000) }
$$


"Carta manuscrita do Padre Fernão de Gouveia ao Padre Geral, de la Baya de todos los S.tos ult. ${ }^{\circ}$ de deziembre de 1583". In Archivum Romanum Societatis Iesu, Roma. Fonte: "Brasiliae 152 (1576-1599)".

(ARSI, [1583], 000)

"Carta do Padre Manoel da Nóbrega, datada de 1556, de Piratininga (São Paulo), dirigida ao Padre Inácio de Loyola, em Roma". In NÓBREGA, Manoel da. S. J. Cartas do Brasil (1549 - 1560), Editora Itatiaia Limitada/Editora da Universidade de São Paulo, Belo Horizonte/São Paulo, 1988.

(Nóbrega, [1556], 000)

"Carta manuscrita sob o título, "O que pareceo ao Padre Visitador Christovão de gouvea ordenar na visita deste Collegio da Baya. $1^{\circ}$ de Janeiro de 1589 . Veo confirmado pelo Padre Geral". In Archivium Romanum Societatis Iesu, Roma. Fonte: Brasiliae 2 (1549-1597).

(ARSI, [1589], 000)

"Ley de dez de Novembro de mil seiscentos quarenta e sete" - Num. II. In Collecção dos Breves Pontificios, e Leys Regias, que foraõ expedidos, e publicadas desde o anno de 1741., sobre a liberdade das pessoas, bens, e commercio dos índios do Brasil; [...], Impressa na Secretaria de Estado, por especial Ordem de Sua Magestade. Fonte: Biblioteca Nacional de Portugal.

(Leys Regias, [1647], 000)

"Carta do Padre Manoel da Nóbrega de 1552, da Bahia, para o Padre Provincial de Portugal”. In NOBREGA, Manoel da. S. J. Cartas do Brasil (1549-1566), Imprensa Nacional, Rio de Janeiro, 1886.

(Nóbrega, [1549], 000)

"Carta do Padre Manoel da Nóbrega, enviada de Pernambuco, a 11 de Agosto de 1551, ao Padre Simão Rodrigues em Lisboa". In HUE, Sheila Moura. Primeiras Cartas do Brasil (1551-1555), Jorge ZAHAR Editor, Rio de Janeiro, 2006.

(Nóbrega, [1551], 000)

"Carta manuscrita do Padre Luís da Grã, de Salvador da Baya da Bahia, a 22 de Setembro de 1561". In Archivum Romanum Societatis Iesu, Roma. Fonte: Brasiliae 15 (15491579).

(ARSI, [1561], 000)

"Carta manuscrita não assinada de 1562". In Archivum Romanum Societatis Iesu, Roma. Fonte: Brasiliae 12 (1562-1574).

(ARSI, [1562], 000)

"Carta do Padre Luiz da Grã ao Padre Inácio de Loyola, da Baía a 27 de Dezembro de 1553". In LEITE, Serafim S. I. Novas Cartas Jesuíticas (De Nóbrega a Vieira), Edições da Companhia Editora Nacional/Brasiliana, São Paulo/Rio de Janeiro/Recife/Porto Alegre, 1940.

(Grã, [1553], 000)

"Carta do Padre Manoel da Nóbrega de 1552, da Bahia, para o Padre Provincial de Portugal". In NOBREGA, Manoel da. S. J. Cartas do Brasil (1549-1566), Imprensa Nacional, Rio de Janeiro, 1886.

(Nóbrega, [1552], 000) 
"Confirmacion que de Roma se embio a la Provincia del Brasil". In Archivium Romanum Societatis Iesu, Roma. Fonte: Brasiliae 2 (1549-1597).

ARSI, [1565], 000)

"Carta manuscrita do Padre General Cláudio Acquaviva para o Padre Provincial Pero Rodriguez de 30 de Junho de 1598". In Archivium Romanum Societatis Iesu, Roma. Fonte: Brasiliae 2 (1549-1597).

(ARSI, [1598], 000)

LEITE, Serafim de S. I. "História da Companhia de Jesus no Brasil", Tomos X, Livraria Portugália/Civilização Brasileira, Lisboa/Rio de Janeiro, 1938-45.

(Leite, [1938-45], 000)

“Carta do Padre Francisco Pires, do Espírito Santo, de 1558”, In Cartas avulsas, 1988.

(Pires, [1558], 000)

VASCONCELOS, Simão de S. J. "Vida do Venerável Padre José de Anchieta”, Lello \& Irmão Editores, Porto, 1953.

(Vasconcelos, [1663], 1953)

"Carta manuscrita do Padre Pero Rodrigues, de 1600". In Archivum Romanum Societatis Iesu, Roma. Fonte: Brasiliae 3-1 (1550-1660).

(Rodrigues, [1600], 000)

STADEN, Hans. "Viagem ao Brasil", Academia Brasileira, Rio de Janeiro, 1930.

(Staden, [1557] 1930, 000)

\section{IV.2 FONTES CONTEMPOR ÂNEAS}

DAEMON, Bazilio Carvalho. "Província do Espírito Santo", Parte II, Typografia do Espírito-Santense, Victória, 1879.

(Daemon, [1879], 000)

Jornal "A Gazeta", A Saga do Espirito Santo - Das Caravelas ao século XXI 19/08/1999. (Gazeta", 1999)

“TELEGRAMA de 04/05/1946 do Secretário Geral do Bispado, Monsenhor José Lidwin, a pedir tombamento da igreja dos jesuítas e da igreja do donatário". Fonte: IPHANRJ. (Telegrama, 1946)

PRINCIPE DE WIED NEUWIED, Maximiliano. "Viagem ao Brasil (1815-17)", Editora Italaia Limitada - Editora da Universidade de São Paulo, Belo Horizonte, 1989.

(Neuwied, [1815-17] 1989)

"Telegrama datado de 02/05/1946 do arquitecto José Carloni, escrito no âmbito do processo de tombamento". Fonte: IPHAN-RJ.

(Telegrama, 1946)

MARTINS, Fausto Sanches. A Arquitectura dos Primeiros Colégios Jesuítas de Portugal: 1542 - 1759, Faculdade de Letras da Universidade do Porto, Porto, 1994. 
PINTO DA SILVA, Maria Madalena. Forma e circunstância. A praça na cidade portuguesa contemporânea, Tese de Doutoramento, FAUP, Porto, 2009.

CUNHA, Maria José. Os Jesuítas no Espírito Santo 1549-1759: contactos confrontos e encontro, Tese de Doutoramento, Universidade de Évora, Évora, 2015.

MAITAM. Fernanda. Jardins Celestes, Jardins Terrenos: A Conversão Jesuíta e a Ocupação do Território na Banda Sul do Brasil, Tese de Doutoramento, Universidade Federal da Bahia, Bahia, 2017.

\section{IV.3 FONTES ICONOGRÁFICAS}

[f1] "Mapa de los confines del Brazil con las tierras de la corona de esp.a en la America Meridonal, s/d. Fonte: Biblioteca Pública Municipal do Porto. Cota C-M\&AP.24(62).

[f2-f3] STADEN, Hans. "Warhaftige Historia und beschreibung eyner landtschafft der Wilnen Nacketen Grimmigen Menschfresser Leuthen in der Newenwelt America”, 1557. (archive.org/details/warhaftigehistor00stad)

[f5] "Mapa da "Província do Espírito Santo", desenhado por José Ribeiro da Fonseca Silvares, 1875”. Fonte: Arquivo Histórico do Exército do Rio de Janeiro.

[f6] "Villa de Guarapari, 1790". Fonte: Arquivo Histórico Ultramarino de Lisboa, AHU_CAR'Tm_007, D. 1050.

“BARRE DE GUARAPARI, DE L'ILE FRANÇAISE ET D'ITAPEMIRIM, 1863". Fonte: Arquivo Histórico do Exército do Rio de Janeiro. Cita: 1183.

Fotografias: Conjunto arquitectónico jesuíta em 1952. Fonte: Arquivo Central do Institurto do Patrimônio Histórico e Artístico Nacional - Secção Rio de Janeiro. 